Original Research Paper

\title{
Penggunaan Metode Permainan Kartesius Dalam Meningkatkan Pengetahuan Dasar Anak Usia 6-12 Tahun di Kecamatam Sape
}

\author{
Rini Andriani ${ }^{1 *}$, Nurkomariah ${ }^{2}$, Nurjariati Fadilah ${ }^{3}$, I Gde Mertha ${ }^{3}$ \\ ${ }^{1}$ Pendidikan Matematika, Fakultas Keguruan dan Ilmu Pendidikan, Universitas Mataram, Indonesia \\ ${ }^{2}$ Pendidikan Bahasa Inggris, Fakultas Keguruan dan Ilmu Pendidikan, Universitas Mataram, Indonesia \\ ${ }^{3}$ Pendidikan Biologi, Fakultas Keguruan dan Ilmu Pendidikan, Universitas Mataram, Indonesia
}

DOI: https://doi.org/10.29303/jpmpi.v3i2.592

Sitasi:. Andriani, R., Nurkomariah., Fadilah, N., \& Mertha, I. G. (2020). Penggunaan Metode Permainan Kartesius Dalam Meningkatkan Pengetahuan Dasar Anak Usia 6-12 Tahun di Kecamatam Sape. Jurnal Pengabdian Magister Pendidikan IPA, 3(2)

\section{Article history \\ Received: 25 Oktober \\ Revised: 15 Nopember \\ Accepted: 29 Desember \\ *Corresponding Author: Nur Hayati, Program Studi \\ Pendidikan Kimia, Fakultas \\ Keguruan dan Ilmu Pendidikan, \\ Universitas Mataram, Mataram, Indonesia \\ Email: hnur63820@gmail.com}

\section{Pendahuluan}

Pembelajaran aktif, kreatif, efektif, dan menyenangkan (PAKEM) memerlukan metode yang bervariasi. Permaianan merupakan salah satu metode pembelajaran yang dapat dimanfaatkan untuk mewujudkan pembelajaran yang bernuansa PAKEM tersebut. Sebagai salah satu metode yang dapat dimanfaatkan untuk menciptakan PAKEM,

\begin{abstract}
Permaianan merupakan salah satu metode pembelajaran yang dapat dimanfaatkan untuk mewujudkan pembelajaran yang bernuansa aktif, kreatif, efektif, dan menyenangkan. Bermain dapat memberikan kesempatan kepada anak untuk memahami dunia, berinteraksi dengan anak lain, mengekspresikan dan mengendalikan emosi, dan mengembangkan kemampuan simbolik sehingga anak aktif membangun pengetahuannya. Perkembangan anak semakin maju jika anak memiliki kesempatan untuk praktik keterampilan-keterampilan yang diperolehnya. Bermain akan banyak melibatkan anak dalam berbagai aktivitas, sehingga konsep-konsep yang diajarkan dapat ditangkap dengan cepat dan mampu bertahan dalam memori anak. Pengabdian ini bertujuan untuk meningkatan kemampuan dasar anak-anak usia 6-12 tahun dan menciptakan pembelajaran yang menyenangkan menggunakan metode permainan bidang kartesius. Kegiatan ini menggabungkan 3 bidang ilmu yaitu IPA, Matematika, dan Bahasa Inggris, dimana Matematika digunakan sebagai media metode permainan bidang kartesius, sedangkan IPA dan Bahasa Inggris menampilkan kumpulan soal disetiap titik pada bidang kartesius. Hasil kegiatan pengabdian menunjukkan penggunaan metode permainan bidang kartesius sangat baik untuk meningkatkan pengetahuan dasar anak karena anak-anak bisa lebih intrekatif. Dengan pembelajaran seperti ini siswa atau anak-anak dapat melaksanakan pembelajaran dengan serius namun menyenangkan serta dapat menghilangkan kejenuhan pada saat pembelajaran karena dalam metode (permainan) ini seluruh siswa atau anak-anak dapat ikut aktif pada setiap permainan yang diadakan.
\end{abstract}

Keywords: Metode Permainan, Bidang Kartesius, Pengetahuan Dasar

metode permaian mempunyai banyak variasi. Banyaknya variasi teknik dalam metode permainan, memungkinkan guru lebih leluasa memilih teknik pembelajaran yang tepat sesuai dengan karakteristik kompetensi dan indikator yang ingin dicapai. Selanjutanya, untuk mewujudkan metode permainan dalam pembelajaran terdapat langkahlangkah penyusunan yang harus dipahami. Permainan merupakan suatu aktivitas untuk 
memperoleh suatu keterampilan tertentu dengan cara menggembirakan (Mardiah, 2015).

Menurut Maryatun dan Hayati (2010) dalam Amiron (2016), menyatakan bahwa bermain dapat memberikan kesempatan kepada anak untuk memahami dunia, berinteraksi dengan anak lain, mengekspresikan dan mengendalikan emosi, dan mengembangkan kemampuan simbolik sehingga anak aktif membangun pengetahuannya. Perkembangan anak semakin maju jika anak memiliki kesempatan untuk praktik keterampilanketerampilan yang diperolehnya. Bermain akan banyak melibatkan anak dalam berbagai aktivitas, sehingga konsep-konsep yang akan diajarkan dapat ditangkap dengan cepat dan mampu bertahan dalam memori anak.

Salah satu aspek yang sangat penting untuk, diketahui dan dipahami dari perkembangan anak usia dasar adalah aspek kognitif. Perkembangan kognitif merupakan suatu perkembangan yang sangat komprehensif yaitu berkaitan dengan kemampuan berfikir, seperti kemampuan bernalar, mengingat, menghafal, memecahkan masalahmasalah nyata, beride dan kreatifitas. Perkembangan kognitif memberikan pengaruh terhadap perkembangan mental dan emosional anak serta kemampuan berbahasa. Sikap dan tindakan anak juga berkaitan dengan kemampuan berfikir anak. Sehingga, perkembangan kognitif dapat dikatakan sebagai kunci dari pada perkembanganperkembangan yang bersifat non-fisik (Bujuri, 2018).

Secara umum kemampuan siswa menyelesaikan atau memahami materi dipengaruhi oleh dua faktor, yaitu faktor internal dan faktor eksternal. Pengetahuan dasar yang dimiliki oleh siswa merupakan faktor internal yang mempengaruhi kemampuan siswa dalam menyelesaikan atau memahami materi. Materi-materi yang terkandung didalamnya tersusun saling mempengaruhi. Faktor disposisi terhadap materi siswa juga berpengaruh terhadap kemampuan siswa dalam menyelesaikan dan memahami materi (Sahrul dan Kadir, 2014).

Pengetahuan dasar yang dibawa siswa dalam situasi belajar dianggap menjadi faktor penting dalam memfasilitasi proses belajar. Terdapat delapan teori untuk menjelaskan pengaruh pengetahuan dasar pada belajar. Teori-teori ini menawarkan berbagai interpretasi tentang bagaimana pengetahuan dasar memberi pengaruh terhadap belajar melalui berbagai proses sebagaimana dijelaskan berikut ini (Sahrul dan Kadir, 2014): (1) Dalam proses pembelajaran, pengetahuan dasar berfungsi sebagai "category label" yang mempengaruhi cara informasi baru yang diperoleh diatur dan ditambahkan kestruktur pengetahuan yang sudah ada (the restructuring approach); (2) Pengetahuan dasar berfungsi sebagai konteks asimilatif di mana materi baru dikaitkan dengan yang telah ada dan akibatnya pengetahuan meningkat dan lebih mudah ditemukan melalui proses elaborasi (the elaboration approach); (3) Aktivasi pengetahuan dasar meningkatkan akses ke pengetahuan tersebut selama proses pembelajaran (the accessibility approach); (4) Pengetahuan dasar mempengaruhi belajar melalui kesiapan yang telah ada sehingga informasi yang relevan dapat diterima dengan lebih siap (the selective attention approach); (5) Pengetahuan dasar mempengaruhi belajar melalui isyarat, semakin banyak pengetahuan dasar yang dimiliki, berarti semakin banyak pengetahuan yang tersedia dalam memori seseorang (the availability approach); (6) Pengaktifan pengetahuan dasar ketika mempelajari materi baru dapat meningkatkan daya ingat dan pengambilan informasi dari pengetahuan yang sudah ada (the retrieval approach); (7) Pengetahuan dasar disusun malalui skema yang mempengaruhi interpretasi dan pemahaman tentang situasi baru (the schema-transfer approach); (8) Pengetahuan dasar yang lebih,berakibat pada pengolahan informasi yang lebih cepat (representation-saving approach).

Selain materi ajar, pemahaman tentang perkembangan kognitif anak juga menjadi pedoman dalam menentukan strategi, model, metode dan teknik evaluasi dalam pembelajaran. Anak akan mudah paham apabila materi yang disampaikan oleh guru menggunakan metode yang sesuai dengan kemampuan berfkir anak. Misalnya, ketika belajar tentang Ilmu Pengetahuan Alam, guru tidak cukup dengan metode ceramah saja, guru mesti menggunakan metode eksperimen (praktek) atau memberikan contoh langsung terkait objek yang dipelajari (modelling), sebab kemampuan berfikir anak usia dasar (7- 11 tahun) berada pada level berfikir konkret (nyata) bukan bersifat khayalan atau sesuatu yang abstrak. Dengan demikian, pemahaman tentang perkembangan kognitif anak usia dasar bukan suatu pemahaman yang dapat dianggap remeh, melainkan pemahaman yang sangat penting terhadap keberhasilan suatu proses 
KBM khususnya pencapaian pada kompetensi kognitif anak (Bujuri, 2018).

Dalam pengabdain ini menggabungkan 3 bidang ilmu yaitu IPA, Matematika dan Bahasa Inggris. dimana matematika digunakan sebagai media yang akan dijadikan sebagai metode permainannya menggunakan bidang kartesius sedangkan IPA dan Bahasa Inggris merupakan kumpulan soal yang terdapat disetiap titik dibidang kartesius yang dibuat. Kegiatan ini berfokus untuk meningkatan kemampuan dasar anak-anak usia 6-12 tahun menggunakan metode permainan bidang kartesius, dan menciptakan pembelajaran yang menyenangkan untuk anak-anak.

\section{Metode}

Metode permainan yang digunakan yaitu menggunakan bidang kartesius, dimana kegiatan dilakukan sebanyak 2 kali. Dalam bidang kartesius yang akan digambarkan terdapat 10 titik pada sumbu X dan 10 titik pada sumbu Y, kemudian untuk sumbu $X$ ke kanan terdapat 5 titik dan sumbu $\mathrm{X}$ kekiri sebanyak 5 titik. Disetiap titik terdapat soal-soal IPA dan Bahasa Inggris yang akan dijawab oleh anak-anak. Anak-anak akan mengambil lot untuk mengetahui berapa langkah yang akan mereka lakukan dalam bidang kartecius tersebut, dititik terakhir anak-anak tersebut berhenti terdapat soal yang diacak baik IPA ataupun Bahasa Inggris yang akan mereka jawab.

\section{Hasil dan Pembahasan}

Dalam permainan ini digunakan bidang kartesius yang digambarkan diatas lapangan voli menggunakan tali rafia dan disetiap titiknya dilambangkan dengan kertas yang bertuliskan angka sesuai dengan bidang kartesius sebenarnya. Dan terdapat juga lot-lot yang berisikan perintah yang akan dilakukan oleh setiap anak, pertanyaanpertanyaan yang akan di jawab oleh anak. dimana terdapat 20 pertanyaan yang mana 10 pertanyaan untuk mata pelajaran Bahasa Inggris dan 10 pertanyaan untuk IPA. Jumlah anak yang ikut serta dalam permainan ini di batasi.

Dalam pengambilan lot ini terdapat 2 ronde agar anak tersebut dapat membandingkan apa yang telah mereka lakukan sebelumnya, dan perlu kita ketahui bahwa bidang kartesius adalah sistem koordinat yang menetapkan setiap titik secara unik dalam bidang dengan serangkaian koordinat numerik, yang merupakan jarak yang bertanda titik dari dua garis berorientasi tegak lurus tetap, diukur dalam satuan panjang yang sama. Setiap garis referensi disebut sumbu koordinat atau hanya sumbu (sumbu jamak) dari sistem, dan titik di mana mereka bertemu adalah asalnya, pada pasangan terurut $(0,0)$. Koordinat juga dapat didefinisikan sebagai posisi proyeksi tegak lurus dari titik ke dua sumbu, yang dinyatakan sebagai jarak yang ditandatangani dari titik asal (Wikipedia, 2020).

Berdasarkan pengamatan hasil permainan yang dilakukan setelah mengambil lot anak-anak mengambil langkah berdasarkan petunjuk yang ada di lot tersebut. Di setiap titik terdapat soal-soal yang harus dijawab oleh anak-anak tersebut. anakanak cukup interakatif, dan cepat tanggap dalam menjawab soal. Soal-soal yang dijawab adalah IPA dan Bahasa Inggris yang tingkat kesulitannya rendah.

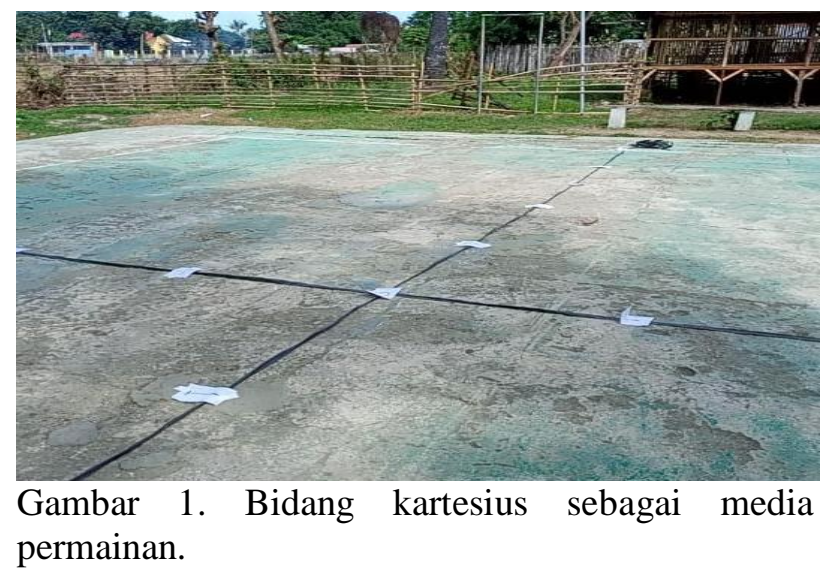

Kemudian anak-anak mengambil lot yang telah disediakan, dimana lot tersebut berisikan perintah berapa langkah yang akan mereka lakukan. Pengambilan lot dilakukan secara acak.

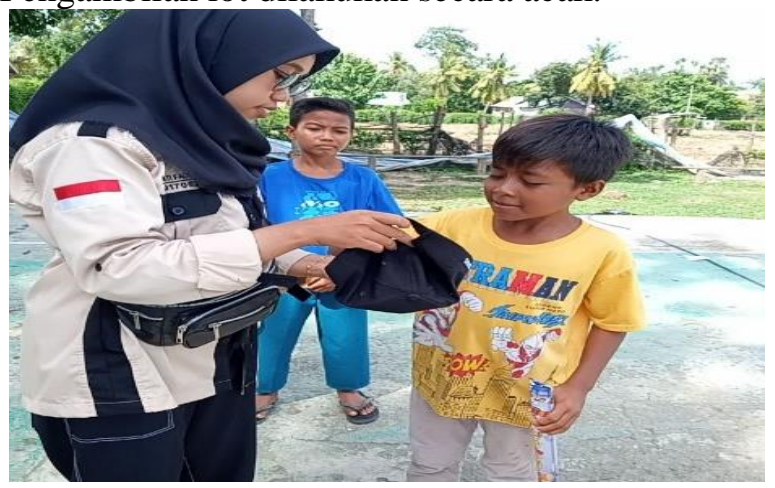

Gambar 2. Pengambilan Lot 
Setelah mengambil lot, dan didapat berapa langkah yang harus mereka lakukan, misalnya majulah 3 langkah ke sumbu $\mathrm{X}$, begitu seterusnya.

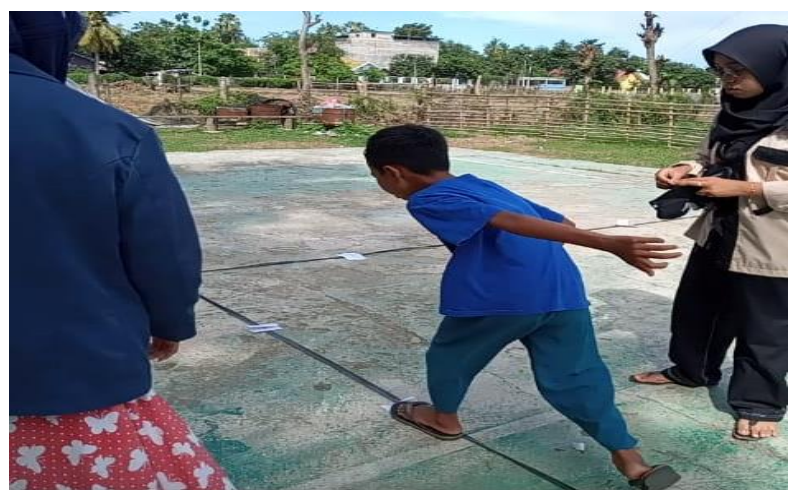

Gambar 3. Melangkah sesuai perintah yang tertera pada lot.

Setelah melangkah sesuai perintah yang tertera pada lot. Anak-anak harus menjawab pertanyaan yang telah dibuat.

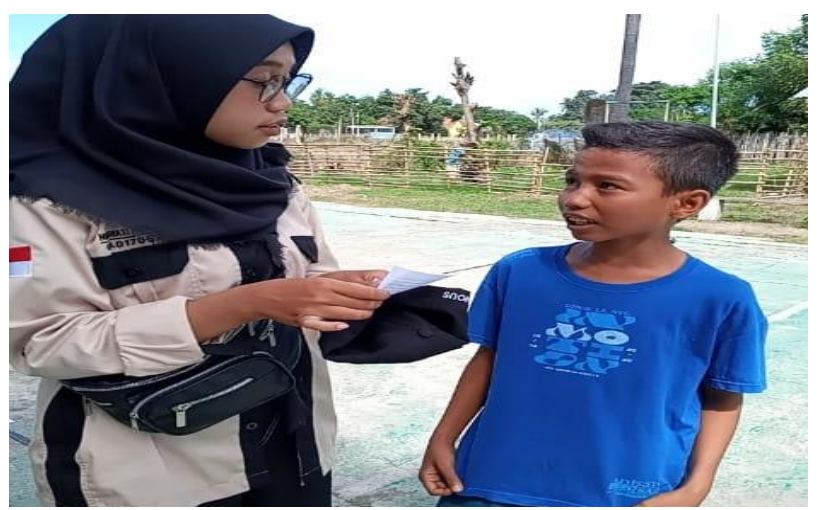

Gambar 4. Menjawab pertanyaan yang diajukan

Penerapan metode permainan pada pembelajaran menggunakan media yaitu bidang kartesius yang menjadi bagian dari ilmu matematika anak-anak akan merasa lebih mudah memahami bidang kartesius dalam ilmu matematika yang menjadi momok atau pelajaran yang tidak terlalu disukai oleh anak-anak. selain itu anak-anak bisa menambah pengetahuan dasarnya dibidang IPA dan Bahasa Inggris. Selain itu metode permainan atau bermain sambil belajar adalah suatu kegiatan terpadu antara belajar dan bermain yang diintegrasikan dalam sebuah materi pelajaran. Dengan pembelajaran seperti ini siswa atau anakanak dapat melaksanakan pembelajaran dengan serius namun menyenangkan serta dapat menghilangkan kejenuhan pada saat pembelajaran karena metode (permainan) ini seluruh siswa atau anak-anak dapat ikut aktif dalam setiap permainan yang diadakan.

\section{Kesimpulan}

Penggunaan metode permainan yaitu bidang kartesius dalam meningkatkan pengetahuan dasar anak, sangat baik karena anak-anak bisa lebih intrekatif dan menciptakan kesan pembelajaran yang menyenangkan dibandingkan dengan proses pembelajaran biasa. Dengan pembelajaran seperti ini siswa atau anak-anak dapat melaksanakan pembelajaran dengan serius namun menyenangkan serta dapat menghilangkan kejenuhan pada saat pembelajaran karena metode (permainan) ini seluruh siswa atau anak-anak dapat ikut aktif dalam setiap permainan yang diadakan.

\section{Ucapan Terima Kasih}

Terimakasih kepada Lembaga Penelitian dan Pengabdian kepada Masyarakat Universitas Mataram atas dukungan dalam kegiatan KKN di Era New Normal tahun akademik 2020-2021 dan anak-anak yang terlibat dalam kegiatan pengabdian.

\section{Daftar Pustaka}

Amiran, Salmon. 2016. Efektifitas Penggunaan Metode Bermain Di Paud Nazareth Oesapa. Jurnal Pendidikan Anak 5 (1): 710-716.

Bujuri, Dian Adesta. 2018. Analisis Perkembangan Kognitif Anak Usia Dasar dan Implikasinya dalam kegiatan Belajar mengajar. Jurnal Literasi IX (1): 37-50.

Mardiah. 2015. Metode Permainan Dalam Pembelajaran Bahasa Indonesia Di Madrasah Ibtidaiyah. Jurnal Mitra PGMI 1 (1): 61-77.

Sahrul dan Kadir. 2014. Pengaruh Pengetahun Dasar Matematika dan Disposisi Matematik Terhadap Kemampuan Menyelesaikan Soal-Soal Limit Fungsi Siswa Kelas XI SMA Negeri 9 Kendari. Jurnal Penelitian Pendidikan Matematika 2 (2): 151-168.

Wikipedia. 2020. Sistem Koordinat Kartesius. Diakses melalui https://id.wikipedia.org/wiki/Sistem koordi nat Kartesius 